\title{
Nitrogen and potassium application by fertigation at different watermelon planting densities
}

\author{
L.A.B. Cecílio Filho*, A. L. Feltrim, J.W. Mendoza Cortez, M.V. Gonsalves, L.C. \\ Pavani, J.C. Barbosa \\ Universidade Estadual Paulista - UNESP, 14884-900, Jaboticabal, São Paulo, Brasil. *Corresponding \\ author: rutra@fcav.unesp.br
}

\begin{abstract}
The effects on the production of 'Top Gun' watermelons were evaluated at $\mathrm{N}$ and $\mathrm{K}\left(\mathrm{N}+\mathrm{K}_{2} \mathrm{O}\right)$ doses via fertigation of $79.8+106.7,106.4+142.2,133.0+177.7$, and $159.6+213.2 \mathrm{~kg} \mathrm{ha}^{-1}$ and at plant spacings of $0.5,1.0$, 1.5 , and $2.0 \mathrm{~m}$. The experiment had a split-plot randomised block design with three replicates. $\mathrm{N}+\mathrm{K}_{2} \mathrm{O}$ doses and plant spacings were randomised in the plots and subplots, respectively. We evaluated foliar $\mathrm{N}$ and $\mathrm{K}$ contents, average mass of commercial fruits (MF), total (FT) and commercial (FC) number of fruits, and total (PT) and commercial (PC) productivity of weight classes $6-8,8-10,10-12$, and $>12 \mathrm{~kg}$ per area and plant. The $\mathrm{N}+\mathrm{K}_{2} \mathrm{O}$ doses only influenced the foliar $\mathrm{K}$ content. The other variables were not influenced by the interaction of factors or by the $\mathrm{N}+\mathrm{K}_{2} \mathrm{O}$ doses. Plant spacing influenced fruit number and production. Reducing plant spacing from 2.0 to $0.5 \mathrm{~m}$ decreased MF, FT, FC, PT, and PC of the classes per plant but increased FT, FC, PT, and PC of the 6-8 and $8-10 \mathrm{~kg}$ classes per area.
\end{abstract}

Keywords: Citrullus lanatus, mineral nutrition, plant spacing

\section{Introduction}

The watermelon (Citrullus lanatus) is the most economic cucurbit produced in Brazil. In 2012, $2079547 \mathrm{t}$ were produced on 94612 ha (FAO, 2014), with $32050 \mathrm{t}$ exported worth US\$ 16523934 (AGROSTAT, 2014). The average Brazilian productivity that year was $22 \mathrm{tha}^{-1}$, very low compared to the global average of $30 \mathrm{tha}^{-1}$. The relentless pursuit of increased crop The average Brazilian productivity that year was $22 \mathrm{t} \mathrm{ha}^{-1}$, very low compared to the global average of $30 \mathrm{tha}^{-1}$. The relentless pursuit of increased crop yields from new cultivars and planting areas and marketing innovations constantly modify cultural practices, highlighting fertilisation management and planting density.

Fertigation is currently a cultural practice with potential use in watermelon crops. Potassium (K) and nitrogen $(\mathrm{N})$ are the nutrients most used in watermelon crops (Grangeiro and Cecílio Filho, 2004; Vidigal et al., 2009; Silva et al., 2012) and can increase productivity and improve fruit quality when applied via fertigation, mainly due to the precise application 
and uniform distribution of these nutrients (Hochmuth, 1992), thereby avoiding environmental problems and reducing the cost of crop production. The use and management of fertigation in watermelon cultivation in Brazil, however, has not been adequately studied.

Planting density and proper management influence crop productivity. High planting densities of several watermelon cultivars have promoted higher numbers of fruits per area (the main component of production that contributes to the increase in productivity) but have decreased the weights and numbers of fruits per plant (NeSmith, 1993; Duthie et al., 1999; Sanders et al., 1999; Garcia and Souza, 2002; Motsenbocker and Arancibia, 2002; Goreta et al., 2005; Miranda et al., 2005; Bastos et al., 2008; Akintoye et al., 2009; Walters, 2009). Akintoye et al. (2009), however, stated that planting density, in addition to the cultivars used, can be dependent on soil and environmental conditions. Watermelon planting density thus requires optimisation for minimising intra-specific competition, and maximising land use and productivity.

The impact of the application of $\mathrm{N}$ and $\mathrm{K}$ associated with different planting densities of watermelons has not been extensively studied, especially when $\mathrm{N}$ and $\mathrm{K}$ are applied without fertigation. The combined application of these nutrients determines the balance between vegetative and reproductive processes in the plants. The recommendations for fertilisation and planting density for watermelons are thus mostly based on non-irrigated crops.

The objective of this study was to evaluate the effect of $\mathrm{N}$ and $\mathrm{K}$ application via fertigation and of spacing between plants within rows on watermelon production.

\section{Materials and Methods}

\subsection{Experimental site and growing conditions}

The experiment was conducted from 5 August to 31 October 2008 in the city of Tupã, São Paulo (215' $05^{\prime \prime S}, 50^{\circ} 30^{\prime} 49^{\prime \prime W} ; 524 \mathrm{~m}$ a.s.1.). Precipitation began 32 days after transplanting (DAT), with higher amounts on 57 DAT $(32.7 \mathrm{~mm})$ and a total of $97.1 \mathrm{~mm}$ during the experimental period. The soil of the area is a red-yellow Podzol (EMBRAPA, 2006) that had been previously cultivated with Brachiaria sp. for 15 years. A chemical analysis of the $0-20 \mathrm{~cm}$ layer indicated a $\mathrm{pH}_{(\mathrm{CaCl} 2)}$ of 4.2 ; organic-matter content of $9.0 \mathrm{~g} \mathrm{dm}^{-3} ; \mathrm{K}$, calcium (Ca), magnesium $(\mathrm{Mg})$, and hydrogen+aluminium contents and sum of bases and cation-exchange capacity ${ }_{(\mathrm{pH}=7)}$ of $1.5,8.0,5.0,18.0$, and $33.0 \mathrm{mmolc}$ $\mathrm{dm}^{-3}$, respectively; phosphorus $(\mathrm{P})_{(\mathrm{resin})}$, boron (B), and zinc ( $\mathrm{Zn})$ contents of 3.0, 0.16, and $0.2 \mathrm{mg} \mathrm{dm}^{-}$ ${ }^{3}$, respectively; and a soil base saturation of $45 \%$.

\subsection{Treatments and experimental design}

Four main treatments $\left(\mathrm{N}+\mathrm{K}_{2} \mathrm{O}\right.$ doses of $79.8+106.7$, $106.4+142.2,133.0+177.7$, and $159.6+213.2 \mathrm{~kg}$ $\mathrm{ha}^{-1}$ ) and four secondary treatments (plant spacings of $0.5,1.0,1.5$, and $2.0 \mathrm{~m}$ ) were arranged in a splitplot randomised block design with three replicates. The reference $\mathrm{N}+\mathrm{K}_{2} \mathrm{O}$ dose $\left(106.4+142.2 \mathrm{~kg} \mathrm{ha}^{-1}\right)$ corresponded to the quantities used for exports of the 'Tide' hybrid watermelon (Grangeiro and Cecílio Filho et al., 2004). The other doses corresponded to 75,125 , and $150 \%$ of the reference dose. 


\subsection{Experimental plots and row spacing}

A plot consisted of three rows with six plants each, with only the central row evaluated. The spacing between rows was $2.0 \mathrm{~m}$.

\subsection{Plant material, planting, and harvesting}

'Top Gun' watermelon seedlings were transplanted when presenting two leaves, 22 days after sowing (8/5/2008). Plants were harvested twice, on 10/20 and $10 / 28 / 2008$ at physiological maturity, indicated by the drying of the tendril closest to the fruit.

\subsection{Crop management}

Agricultural lime with $120 \%$ PRNT (total neutralisation relative power) was used to raise the soil base saturation to $70 \%$, as recommended by Trani et al. (1997). Organic fertiliser was not used. At planting, $240 \mathrm{~kg} \mathrm{ha}^{-1}$ of $\mathrm{P}_{2} \mathrm{O}_{5}$ (superphosphate) were applied, as were $40 \mathrm{~kg} \mathrm{ha}^{-1}$ of $\mathrm{MgSO}_{4}$ (magnesium sulphate) to increase the $\mathrm{Mg}$ content to $9 \mathrm{mmolc} \mathrm{dm}^{-3}$, as recommended by Trani et al. (1997).

A drip-irrigation system was used. Irrigation water was obtained from an artesian well and contained 35, $0.75,8.0,4.0,0.1,1.9,0.8,<0.1$, and $0.85 \mathrm{mg} \mathrm{L}^{-1}$ of $\mathrm{CaCO}_{3}$, sodium, $\mathrm{Ca}, \mathrm{Mg}, \mathrm{B}$, chlorine, fluorine, iron, and carbon, respectively; an electrical conductivity of $0.12 \mathrm{dS} \mathrm{m}^{-1}$; a $\mathrm{pH}$ of 6.36 ; and a sodium adsorption ratio of 0.05 . The amount of irrigation was determined from the reference evapotranspiration through a Class A tank. The reference evapotranspiration (ETo) was calculated as:

$\mathrm{ETo}=\mathrm{ETA} \times \mathrm{Kp}$

where ETA is the water evaporated from the Class A tank, and the coefficient $\mathrm{Kp}$ is 0.7 . The daily crop evapotranspiration (ETc) was calculated as:

$\mathrm{ETc}=$ Eto $\times \mathrm{Kc}$ where $\mathrm{Kc}=0.4$ (initial stage, $0-15 \mathrm{DAT}), \mathrm{Kc}=0.4-$ 1.0 (rapid vegetative growth, $16-32 \mathrm{DAT}$ ), $\mathrm{Kc}=1.0$ (intermediate phase, 33-75 DAT), and $\mathrm{Kc}=0.75-1.0$ (final phase, 76 DAT to harvest) (Allen et al., 1998). $\mathrm{N}+\mathrm{K}_{2} \mathrm{O}$ doses were applied individually to each treatment. The $\mathrm{N}$ and $\mathrm{K}$ sources were ammonium nitrate, potassium nitrate, and potassium chloride. The $\mathrm{N}+\mathrm{K}_{2} \mathrm{O}$ doses were applied in 28 fertigations, with $20 \%$ of the total for each treatment applied in the first nine fertigations. The fertigation began and ended at 3 and 65 DAT, respectively. For all treatments, $3 \mathrm{~kg} \mathrm{ha}^{-1}$ of B (boric acid) and Zn (zinc sulphate) were applied at 15 and $30 \mathrm{DAT}$, respectively, via fertigation. At the beginning of flowering, $1.45 \mathrm{~kg} \mathrm{ha}^{-1}$ of $\mathrm{Ca}$ (calcium nitrate) were applied in each fertigation and in equal quantities to prevent rotting. The $\mathrm{N}$ provided by the calcium nitrate was added to the $\mathrm{N}$ supplied by the ammonium nitrate and potassium nitrate for calculating the total added for the treatment. Three beehives were distributed around the experimental area at 25 DAT to ensure pollination.

Phytosanitary control used products registered for culture. Insecticides were sprayed after installation of the beehives in late afternoon three times a week until early fruiting and then twice a week until 21 days before the harvest. Narrow-leaved weeds were controlled with a selective herbicide, and broadleaved weeds were controlled manually.

\subsection{Parameters evaluated}

The following parameters were evaluated: a) foliar $\mathrm{N}$ and $\mathrm{K}$ contents of diagnostic leaves (Trani and Raij, 1997), b) total number of fruits (FT), c) number of commercial fruits (FC) ( $\geq 6 \mathrm{~kg}$, without cracking or rot), d) number of fruits of 6-8 $\mathrm{kg}\left(\mathrm{F}_{6-8}\right), 8-10 \mathrm{~kg}\left(\mathrm{~F}_{8}\right.$ $\left.{ }_{10}\right), 10-12 \mathrm{~kg}\left(\mathrm{~F}_{10-12}\right)$, and $>12 \mathrm{~kg}\left(\mathrm{~F}_{>12}\right)$, e) fruit weight (commercial fruit only), f) total productivity (TP), g) commercial productivity $(\mathrm{PC})$, and h) productivities 
of fruits of 6-8 $\mathrm{kg}\left(\mathrm{P}_{6-8}\right), 8-10 \mathrm{~kg}\left(\mathrm{P}_{8-10}\right), 10-12 \mathrm{~kg}\left(\mathrm{P}_{10-}\right.$ $\left.{ }_{12}\right)$, and $>12 \mathrm{~kg}\left(\mathrm{P}_{>12}\right)$. All evaluations were made by plant (number of fruits plant ${ }^{-1}, \mathrm{~kg} \mathrm{plant}^{-1}$ ) and area (number of fruits $\mathrm{ha}^{-1}, \mathrm{~kg} \mathrm{ha}^{-1}$ ) of the subplots. Area productivity was calculated for an effective cultivation of $10000 \mathrm{~m}^{2}$.

\subsection{Statistical analysis}

The data were analysed by $\mathrm{F}$ tests and, when significant, were subjected to polynomial regression using SAS (SAS Institute, 2000).

\section{Results and Discussion}

\subsection{Foliar $N$ and $K$ contents}

The interaction between $\mathrm{N}+\mathrm{K}_{2} \mathrm{O}$ dose and spacing was not significant, and $\mathrm{N}+\mathrm{K}_{2} \mathrm{O}$ dose and spacing individually did not significantly affect foliar $\mathrm{N}$ content (Table 1). Average foliar $\mathrm{N}$ content $\left(30 \mathrm{~g} \mathrm{~kg}^{-1}\right)$ was within the range ( 25 to $50 \mathrm{~g} \mathrm{~kg}^{-1}$ ) recommended for watermelons by Trani and Raij (1997).

Table 1. Analysis of variance of $\mathrm{N}$ and $\mathrm{K}$ contents in the diagnostic leaves as functions of the $\mathrm{N}+\mathrm{K}_{2} \mathrm{O}$ dose and the spacing between 'Top Gun' watermelon plants.

\begin{tabular}{ccc}
\hline Causes of variation & N content & K content \\
\hline Dose $\mathrm{N}+\mathrm{K}_{2} \mathrm{O}(\mathrm{D})$ & $0.99^{\mathrm{ns}}$ & $0.48^{*}$ \\
Spacing (S) & $1.43^{\mathrm{ns}}$ & $4.33^{\text {ns }}$ \\
$\mathrm{D} \times \mathrm{S}$ & $1.16^{\mathrm{ns}}$ & $0.84^{\mathrm{ns}}$ \\
\hline $\mathrm{CV}(\%)$ & 5.02 & 12.56
\end{tabular}

*, ns: significant and not significant, respectively, at $5 \%$ probability in an $\mathrm{F}$ test

$\mathrm{N}+\mathrm{K}_{2} \mathrm{O}$ dose, however, had a significant effect on foliar $\mathrm{K}$ content (Table 1).

Foliar K content increased linearly with $\mathrm{N}+\mathrm{K}_{2} \mathrm{O}$ dose $\left(\mathrm{y}=27.69+3.68 \mathrm{x}, \mathrm{R}^{2}=0.95^{* *}\right)$ and was within the range ( 25 to $40 \mathrm{~g} \mathrm{~kg}^{-1}$ ) recommended for watermelons by Trani and Raij (1997).
3.2. Fruit number and productivity per plant and per hectare

The interaction between $\mathrm{N}+\mathrm{K}_{2} \mathrm{O}$ and spacing was not significant, and $\mathrm{N}+\mathrm{K}_{2} \mathrm{O}$ dose did not significantly affect the number or total (FT, PT) or commercial (FC, $\mathrm{PC})$ productivity for the $6-8 \mathrm{~kg}\left(\mathrm{~F}_{6-8}, \mathrm{P}_{6-8}\right), 8-10 \mathrm{~kg}$ $\left(\mathrm{F}_{8-10}, \mathrm{P}_{8-10}\right), 10-12 \mathrm{~kg}\left(\mathrm{~F}_{10-12}, \mathrm{P}_{10-12}\right)$, and $>12 \mathrm{~kg}\left(\mathrm{~F}_{>12}\right.$, $\mathrm{P}_{>12}$ ) classes, either per plant or per hectare (Table 2). 
Table 2. Analysis of variance for total fruit (FT, PT) and commercial number and productivity (FC, PC) of fruit for the 6-8 $\mathrm{kg}\left({ }_{\mathrm{F}-\mathrm{-}-8}, \mathrm{P}_{6-8}\right), 8-10 \mathrm{~kg}\left(\mathrm{~F}_{8-10}, \mathrm{P}_{8-10}\right), 10-12 \mathrm{~kg}\left(\mathrm{~F}_{10-12}, \mathrm{P}_{10-12}\right)$, and $>12 \mathrm{~kg}\left(\mathrm{~F}_{>12}, \mathrm{P}_{>12}\right)$ classes and for average fruit weight (MF) per plant and per hectare as functions of the $\mathrm{N}+\mathrm{K}_{2} \mathrm{O}$ dose and the spacing between 'Top Gun' watermelon plants.

\begin{tabular}{|c|c|c|c|c|c|c|c|c|c|c|c|c|c|}
\hline $\begin{array}{l}\text { Causes of } \\
\text { variation }\end{array}$ & FT & FC & $\mathrm{F}_{6-8}$ & $F_{8-10}$ & $F_{10-12}$ & $\mathrm{~F}_{>12}$ & PT & $\mathrm{PC}$ & $P_{6.8}$ & $P_{8-10}$ & $P_{10-12}$ & $P_{>12}$ & MF \\
\hline \multicolumn{14}{|c|}{ per plant } \\
\hline Dose $\mathrm{N}+\mathrm{K}_{2} \mathrm{O}(\mathrm{D})$ & $1.56^{\mathrm{ns}}$ & $2.72^{\mathrm{ns}}$ & $1.23^{\mathrm{ns}}$ & $0.54^{\mathrm{ns}}$ & $2.09^{\mathrm{ns}}$ & $0.50^{\mathrm{ns}}$ & $2.12^{\mathrm{ns}}$ & $1.55^{\mathrm{ns}}$ & $1.34^{\mathrm{ns}}$ & $0.47^{\mathrm{ns}}$ & $2.10^{\mathrm{ns}}$ & $0.44^{\mathrm{ns}}$ & $0.16^{\mathrm{ns}}$ \\
\hline Spacing (S) & $51.29 * *$ & $37.82^{* *}$ & $7.42^{* * *}$ & $4.01^{* *}$ & $10.47^{* *}$ & $6.87^{* * *}$ & $57.38^{* *}$ & $41.75^{* *}$ & $7.89^{* *}$ & $3.88^{*}$ & $10.59^{* *}$ & $6.91^{* * *}$ & $5.10^{* *}$ \\
\hline $\mathrm{D} \times \mathrm{S}$ & $0.71^{\mathrm{ns}}$ & $0.41^{\mathrm{ns}}$ & $0.25^{\mathrm{ns}}$ & $0.50^{\mathrm{ns}}$ & $0.93^{\mathrm{ns}}$ & $0.61^{\mathrm{ns}}$ & $0.33^{\mathrm{ns}}$ & $0.47^{\text {ns }}$ & $0.31^{\mathrm{ns}}$ & $0.44^{\mathrm{ns}}$ & $0.97^{\mathrm{ns}}$ & $0.61^{\mathrm{ns}}$ & $0.30^{\mathrm{ns}}$ \\
\hline CV (\%) & 15.82 & 16.64 & 34.49 & 37.53 & 42.74 & 85.20 & 17.22 & 15.07 & 33.38 & 37.84 & 42.79 & 85.82 & 6.14 \\
\hline \multicolumn{14}{|c|}{ per hectare } \\
\hline Dose $\mathrm{N}+\mathrm{K}_{2} \mathrm{O}(\mathrm{D})$ & $2.43^{\mathrm{ns}}$ & $1.42^{\mathrm{ns}}$ & $1.46^{\mathrm{ns}}$ & $0.64^{\mathrm{ns}}$ & $2.11^{\mathrm{ns}}$ & $0.08^{\mathrm{ns}}$ & $0.97^{\mathrm{ns}}$ & $1.19^{\mathrm{ns}}$ & $1.86^{\mathrm{ns}}$ & $0.57^{\mathrm{ns}}$ & $1.96^{\mathrm{ns}}$ & $0.07^{\mathrm{ns}}$ & - \\
\hline Spacing (S) & $42.48^{* *}$ & $23.06^{* *}$ & $10.62^{* *}$ & $9.49^{* *}$ & $1.22^{\mathrm{ns}}$ & $3.30^{*}$ & $33.69^{* *}$ & $19.97^{* *}$ & $11.60^{* *}$ & $10.02^{* *}$ & $1.15^{\mathrm{ns}}$ & $3.30^{*}$ & - \\
\hline $\mathrm{DXS}$ & $0.70^{\mathrm{ns}}$ & $0.76^{\mathrm{ns}}$ & $0.23^{\mathrm{ns}}$ & $0.63^{\mathrm{ns}}$ & $0.84^{\mathrm{ns}}$ & $0.61^{\mathrm{ns}}$ & $0.55^{\mathrm{ns}}$ & $0.89^{\mathrm{ns}}$ & $0.27^{\mathrm{ns}}$ & $0.54^{\mathrm{ns}}$ & $0.86^{\mathrm{ns}}$ & $0.64^{\mathrm{ns}}$ & - \\
\hline CV (\%) & 15.21 & 21.65 & 51.42 & 42.49 & 46.09 & 83.26 & 15.41 & 19.78 & 49.68 & 41.85 & 45.79 & 82.72 & - \\
\hline
\end{tabular}

*, ns: significant and not significant, respectively, at $5 \%$ probability in an $\mathrm{F}$ test; **: significant at $1 \%$ probability in an $\mathrm{F}$ test

The lack of response to increasing $\mathrm{N}+\mathrm{K}_{2} \mathrm{O}$ doses can be attributed to the lack of significant effects on the foliar N contents. Foliar K content, however, increased significantly, and all levels of this nutrient were within the sufficiency range for watermelon. The lowest dose of $\mathrm{N}+\mathrm{K}_{2} \mathrm{O}\left(79.8+106.7 \mathrm{~kg} \mathrm{ha}^{-1}\right)$ was able to meet the demand of the 'Top Gun' hybrid, perhaps because fertigation stimulates the root system, favouring the efficiency of nutrient absorption and therefore reducing the amount of fertiliser needed (Rana et al., 2014). Our results agreed with those by Feltrim et al. (2011) for $\mathrm{N}+\mathrm{K}_{2} \mathrm{O}$ doses (via fertigation) and row spacing in the 'Shadow' seedless hybrid watermelon. Goreta et al. (2005) reported no differences in the effects of $\mathrm{N}$ doses $\left(115,195\right.$, and $275 \mathrm{~kg} \mathrm{ha}^{-1}, 35 \mathrm{~kg} \mathrm{ha}^{-1}$ applied pre-planting and the rest in fertigation) on PT and PC of 'Crimson Sweet' watermelons. Andrade Junior et al. (2005; 2006), however, reported that $\mathrm{N}$ and
$\mathrm{K}$ doses $\left(0,40,80,120\right.$, and $\left.160 \mathrm{~kg} \mathrm{ha}^{-1}\right)$ applied via fertigation on 'Crimson Sweet' watermelons affected FT, FC, PT, and PC.

The lowest $\mathrm{N}+\mathrm{K}_{2} \mathrm{O}$ dose in our study $(79.8+106.7 \mathrm{~kg}$ $\mathrm{ha}^{-1}$ ), considered appropriate for meeting the productive potential of the 'Top Gun' hybrid, was similar to the dose identified by Andrade Junior et al. (2005; 2006) for producing approximately $60 \mathrm{tha}^{-1}$ of 'Crimson Sweet' watermelons, and represented $25 \%$ less $\mathrm{N}$ and $\mathrm{K}_{2} \mathrm{O}$ for producing 'Tide' hybrid watermelons exported at $40 \mathrm{t} \mathrm{ha}^{-1}$ (Grangeiro and Cecílio Filho et al., 2004).

Plant spacing significantly affected FT, PT, FC, and $\mathrm{PC}$ in different classes, when evaluated per plant (Table 2). FT and FC per plant increased linearly (Figure $1 \mathrm{~A}$ and $1 \mathrm{~B}$ ) as the spacing between plants increased from 0.5 to $2.0 \mathrm{~m} . \mathrm{F}_{6-8}$ and $\mathrm{F}_{8-10}$, which together accounted for approximately $70 \%$ of the commercial 
fruit at the evaluated spacing, increased by 80 and $54 \%$, respectively, when the spacing increased from 0.5 to $2.0 \mathrm{~m}$. Resende and Costa (2003), Goreta et al. (2005), and Miranda et al. (2005) also reported higher numbers of 'Crimson Sweet' watermelons per plant as row spacing increased from 0.4 to $1.5 \mathrm{~m}$. Increasing the spacing between plants from 0.3 to $2.5 \mathrm{~m}$ also increased the number of triploid (seedless) watermelons per plant (Motsenbocker and Arancibia, 2002; Walters, 2009; Feltrim et al., 2011). Ramos et al. (2009), however, reported no statistical difference in the number of fruits per plant between plant spacings of $2.0 \times 0.5,2.0$ $\times 0.4$, and $2.0 \times 0.3 \mathrm{~m}$.

$\mathrm{PT}, \mathrm{PC}$, and productivity per plant in the classes increased linearly with larger spacings between plants (Figure 1C and 1D) due to the positive influence of the larger number of fruits per plant. PC increased by $125 \%$, especially for $\mathrm{P}_{8-10}$, for the lowest plant density evaluated $(2.0 \times 2.0$ m). Motsenbocker and Arancibia (2002) and Goreta et al. (2005) also observed linear increases in productivity per plant at lower plant densities.

Increased spacing among plants increased the number of non-commercial fruits $(<6 \mathrm{~kg})$. The number of non-commercial fruits was $34 \%$ of FT at $0.5 \mathrm{~m}$ between plants but was $39 \%$ at $2.0 \mathrm{~m}$ between plants. The number of non-commercial fruits, associated with the increase in FT, increased from 1.5 fruits plant ${ }^{-1}$ at the closer spacing $(0.5 \mathrm{~m})$ to 3.4 fruits plant ${ }^{-1}$ at the largest spacing $(2.0 \mathrm{~m})$. This $126 \%$ increase in FT was due to the later setting of fruits by the plants. These fruits have thus not reached the commercial weight of $6 \mathrm{~kg}$ or an appropriate quality. Branches, leaves, petioles, and stems are damaged during the first harvest, leading to more pathogenic attack and plant senescence. PC per plant under the same conditions, however, decreased from 79 to $77 \%$ of PT due to the higher average weight at larger spacings.

Plant spacing significantly influenced total (FT, PT) and commercial (FC, PC) fruit number and produc- tivity in the $\mathrm{F}_{6-8}, \mathrm{~F}_{8-10}, \mathrm{~F}_{>12}, \mathrm{P} 6-8, \mathrm{P}_{8-10}$, and $\mathrm{P}_{>12}$ classes (Table 2). All these responses to increases in plant spacing were fitted to linear and quadratic equations (Figure 2A-D). The responses, however, were described inversely to the increased spacing observed for the evaluated and expressed characteristics per plant. That is, an increase in plant spacing caused a reduction in FT and PT, FC and PC, $\mathrm{F}_{6-8}$ and $\mathrm{P}_{6-8}, \mathrm{~F}_{8-10}$ and $\mathrm{P}_{8-10}$, and $\mathrm{F}_{>12}$ and $\mathrm{P}_{>12}$ per hectare. This relationship has also been observed in other studies (NeSmith, 1993; Duthie et al., 1999; Sanders et al., 1999; Motsenbocker and Arancibia, 2002; Goreta et al., 2005; Walters, 2009), but with variation in the response of the various cultivars used. Ramos et al. (2009) reported statistical differences only in PC and not in PT among watermelon cultivars, with higher values at lower plant spacings (0.3 and $0.4 \mathrm{~m}$ ). Bastos et al. (2008), however, found a higher PT in 'Mickylee' watermelons at the largest plant spacing $(2.0 \times 1.2 \mathrm{~m})$. PC and PT for 'Crimson Sweet' watermelons did not differ between the lowest $(2.0 \times 1.0 \mathrm{~m}$ and one plant per hole $)$ and highest $(2.0 \times 1.0 \mathrm{~m}$ and $2.0 \times 1.5 \mathrm{~m}$, with two plants per hole $)$ planting density (Miranda et al., 2005).

The 121 and 107\% increases in the FT and FC per plant, respectively, due to wider spacing were not sufficient to compensate the lower FT per hectare. The wider spacing $\left(2500\right.$ plants $\left.\mathrm{a}^{-1}\right)$ consequently produced the lowest FT, $\mathrm{FC}$, and $\mathrm{F}_{8-10}$ per hectare despite the significant increase in fruit number per plant. For example, FC decreased by $43.5 \%$ at a spacing of $2.0 \mathrm{~m}$ relative to $0.5 \mathrm{~m}$ among plants, which resulted in 5018 fewer fruits per hectare.

The large increase in the number of fruits per hectare as the spacing between plants decreased caused a proportional increase in productivity. PC was approximately $81 \%$ higher $\left(59.2 \mathrm{tha}^{-1}\right)$ at $0.5 \mathrm{~m}$ between plants than at $2.0 \mathrm{~m}$ between plants, even with the $117 \%$ higher PC per plant at $2.0 \mathrm{~m}$ between plants relative to $0.5 \mathrm{~m}$. The largest $\mathrm{PC}$ of $\mathrm{P}_{6-8}$ and $\mathrm{P}_{8-10}$ classes were 24.4 and $22.8 \mathrm{t} \mathrm{ha}^{-1}$, respectively (Figure 2D), which correspond to $76.5 \%$ of the PC. The average productivity for $\mathrm{P}_{10-12 \text {, which was not }}$ 
significantly influenced by the spacing (Table 2), was $10.8 \mathrm{t} \mathrm{ha}^{-1}$. The number of fruit and yield per hectare decreased for $\mathrm{F}_{6-8}$ and $\mathrm{P}_{6-8}$ at a spacing of $1.6 \mathrm{~m}$ but increased for $\mathrm{F}_{>12}$ and $\mathrm{P}_{>12}$ at a spacing of $1.4 \mathrm{~m}$ (Figure 2B and 2D).

\subsection{Average fruit weight}

The average fruit weight (MF) was significantly influenced only by spacing between plants (Table 2). MF fitted significantly to a quadratic model (y $\left.=7.484+2.299 \mathrm{x}-0.749 \mathrm{x}^{2}, \mathrm{R}^{2}=0.94^{* *}\right)$. The highest and lowest MFs were obtained at spacings of $1.7 \mathrm{~m}$ (9.2 kg fruit $\left.{ }^{-1}\right)$ and $0.5 \mathrm{~m}\left(8.4 \mathrm{~kg}\right.$ fruit $\left.^{-1}\right)$. NeSmith (1993), Duthie et al. (1999), Sanders et al. (1999),
Garcia and Souza (2002), Motsenbocker and Arancibia (2002), Goreta et al. (2005), Miranda et al. (2005), Bastos et al. (2008), and Walters (2009) also reported decreases in fruit weight with plant spacing in various watermelon cultivars, a result of increased intra-specific competition for light, water, and nutrients, which may delay ontogenetic events vital to fruit development and contribute substantially to potential reductions in crop yield. Ramos et al. (2009) and Feltrim et al. (2011), however, found no significant effect of increased spacing ( 0.3 to $2.0 \mathrm{~m}$ ) on fruit weight, which may have been due to the use of cultivars with smaller fruits (averages of 3.8 and $5.5 \mathrm{~kg}$ ) that did not respond to the changes in spacing between plants.
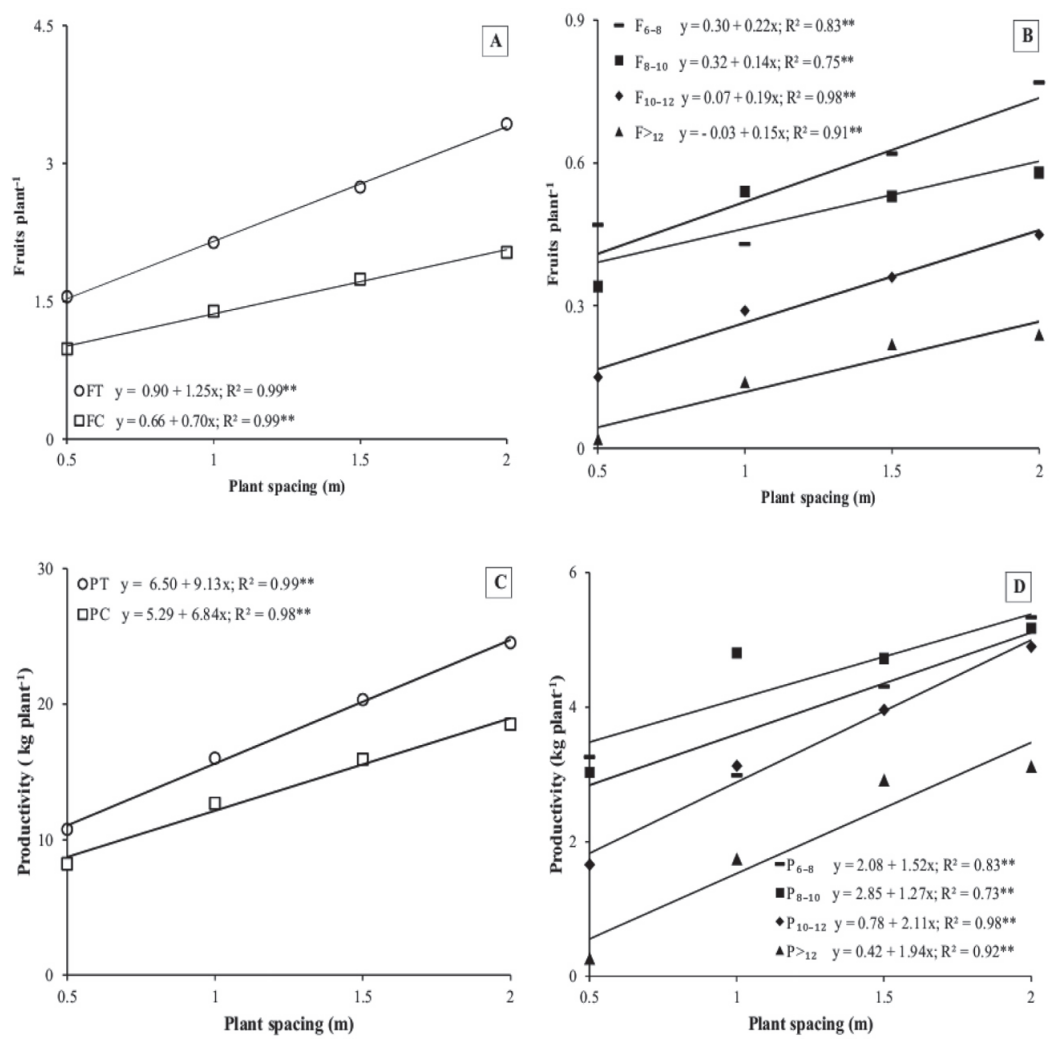

Figure 1. Fruit number $(\mathrm{A}, \mathrm{B})$ and total $(\mathrm{FT}, \mathrm{PT})$ and commercial $(\mathrm{FC}, \mathrm{PC})$ productivity $(\mathrm{C}, \mathrm{D})$ for the $6-8 \mathrm{~kg}\left(\mathrm{~F}_{6-8}, \mathrm{P}_{6-8}\right), 8-10 \mathrm{~kg}$ $\left(\mathrm{F}_{8-10}, \mathrm{P}_{8-10}\right), 10-12 \mathrm{~kg}\left(\mathrm{~F}_{10-12}, \mathrm{P}_{10-12}\right)$, and $>12 \mathrm{~kg}\left(\mathrm{~F}_{>12}, \mathrm{P}_{>12}\right)(\mathrm{B}, \mathrm{D})$ classes per plant as functions of the spacing between 'Top Gun' watermelon plants. 

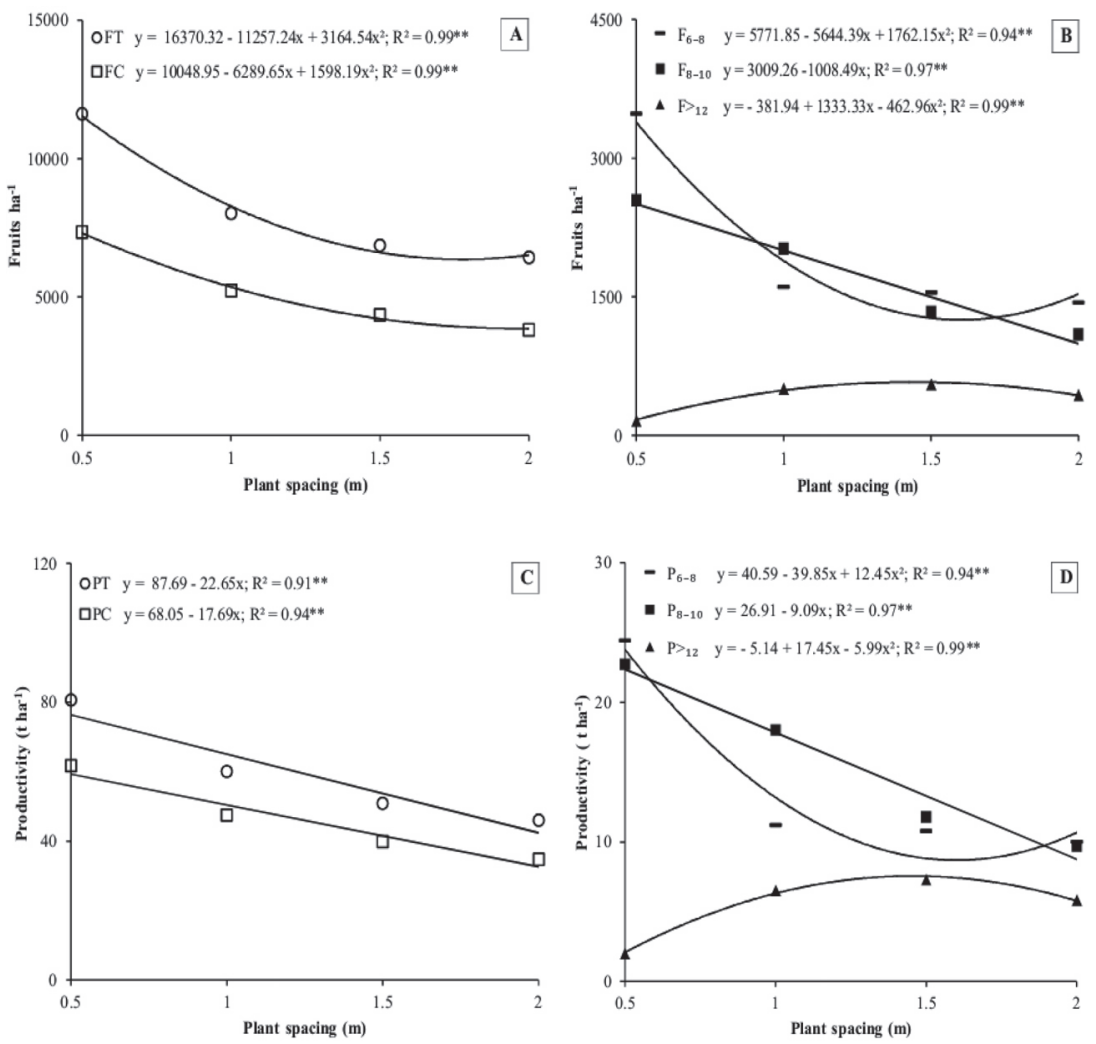

Figure 2. Fruit number (A, B) and total (FT, PT) and commercial (FC, PC) productivity (C, D) for the 6-8 $\mathrm{kg}\left(\mathrm{F}_{6-8}\right.$, $\left.\mathrm{P}_{6-8}\right), 8-10 \mathrm{~kg}\left(\mathrm{~F}_{8-10}, \mathrm{P}_{8-10}\right)$, and $>12 \mathrm{~kg}\left(\mathrm{~F}_{>12}, \mathrm{P}_{>12}\right)(\mathrm{B}, \mathrm{D})$ classes per hectare as functions of the spacing between 'Top Gun' watermelon plants.

\section{Conclusions}

Increasing the doses of nitrogen and potassium did not increase watermelon production. Reducing the spacing between plants from 2.0 to $0.5 \mathrm{~m}$ decreased fruit production per plant but increased fruit production per area. The weights of watermelons decreased with the reduction of the spacing between plants. A plant spacing of $0.5 \mathrm{~m}$ and lower doses of nitrogen $\left(79.8 \mathrm{~kg} \mathrm{ha}^{-1}\right)$ and potassium (106.7 $\left.\mathrm{kg} \mathrm{ha}^{-1}\right)$ produced the highest yields of watermelons.

\section{Acknowledgments}

To FAPESP (Research Funding Foundation of São Paulo State) for financing this research project and to BIOTEK for the assignment of facilities and the technological support.

\section{References}

Akintoye, H.A., Kintomo, A. A., Adekunle, A.A. 2009. Yield and fruit quality of watermelon in response to plant population. International Journal of Vegetable Science. 15, 369-380. 
Andrade Junior, A. S., Dias, N. da S., Figueredo Junior, L.G.M., Daniel, R., Ribeiro, V.Q. 2005. Doses de potássio via fertirrigação na produção e qualidade de frutos de melancia em Parnaíba, PI. Irriga. 10, 205-214.

Andrade Junior, A.S. de, Dias, N. da S., Figueiredo Junior, L.G.M., Ribeiro, V.Q., Sampaio, D.B. 2006. Produção e qualidade de frutos de melancia à aplicação de nitrogênio via fertirrigação. Rev. Bras. Eng. Agríc. Ambient. 10, 836-841.

AGROSTAT. 2014. Estatística do Comércio Exterior do Agronegócio Brasileiro. Available at: http://sistemasweb.agricultura.gov.br/pages/AGROSTAT.html

Allen, R.G., Pereira, L.S., Raes, D., Smith, M. 1998. Crop Evapotranspiration: Guidelines for Computing Crop Water Requirements (Irrigation and Drainage Paper, 56). FAO, Roma, 300 p.

Bastos, F.G.C., Azevedo, B.M. de, Rego, J. de L., Viana, T.V. de A., D’Ávila, J. H.T. 2008. Efeitos de espaçamentos entre plantas na cultura da melancia na Chapada do Apodi, Ceará. Rev. Ciênc. Agron. 39, 240-244.

Duthie, J.A., Schrefler, J. W., Roberts, B.W., Edelson, J.V. 1999. Plant density-dependent variation in marketable yield, fruit biomass, and marketable fraction in watermelon. Crop Sci. 39, 406-412.

EMBRAPA. 2006. Sistema Brasileiro de Classificação de Solos. Embrapa Solos, Rio de Janeiro, 306 p.

FAO. 2014. FAOSTAT. Available at: http://faostat3. fao.org/download/Q/QC/E

Feltrim, A.L., Cecílio Filho, A.B., Gonsalves, M.V., Pavani, L.C., Barbosa, J.C., Mendoza Cortez, J. W. 2011. Distancia entre plantas y dosis de nitrógeno y potasio en sandía sin semillas fertirrigada. Pesq. Agropec. Bras. 46, 985-991.

García, L.F., Souza, V.A.B. de. 2002. Influência do espaçamento e da adubação nitrogenada sobre a produção da melancia. Revista Fac. Agron. (Maracay) $28,59-70$.
Goreta, S., Perica, S., Duminic, G., Bucan, L., Zanic, K. 2005. Growth and yield of watermelon on polyethylene mulch with different spacings and nitrogen rates. HortScience. 40, 366-369.

Grangeiro, L.C, Cecílio Filho, A.B. 2004. Acúmulo e exportação de macronutrientes pelo híbrido de melancia Tide. Hortic. Bras. 22, 93-97.

Hochmuth, G.J. 1992. Fertilizer management for drip-irrigated vegetables in Florida. HortTechnology. 2, 27-32.

Miranda, F.R. de, Montenegro, A.A.T., Oliveira, J.J.G. 2005. Produtividade da melancia irrigada por gotejamento em diferentes espaçamentos de plantio. Rev. Ciênc. Agron. 36, 158-162.

Motsenbocker, C.E., Arancibia, R.A. 2002. In-row spacing influences triploid watermelon yield and crop value. HortTechnology. 12, 437-440.

Nesmith, D.S. 1993. Plant spacing influences watermelon yield and yield components. HortScience. 28, 885-887.

Ramos, A.R.P, Dias, R. de C.S., Aragão, C.A. 2009. Densidades de plantio na produtividade e qualidade de frutos de melancia. Hortic. Bras. 27, 560-564.

Rana, R., Ramesh, Kaushal, S., Guleria, G. 2014. Fertigation: a tool for efficient fertilizer and water management. Popular Kheti. 2, 37-44.

Resende, G. M. de, Costa, N. D. 2003. Características produtivas da melancia em diferentes espaçamentos de plantio. Hortic. Bras. 21, 695-698.

SAS Institute. 2000. SAS Procedures Guide for Computers, Version 8.1. SAS Institute, Cary, $1686 \mathrm{p}$.

Sanders, D. C., Cure, J. D., Schultheis, J. R. 1999. Yield response of watermelon to planting density, planting pattern, and polyethylene mulch. HortScience. 34, 1221-1223. 
Silva, M. V. T. da, Chaves, S. W. P., Medeiros, J. F. de, Souza, M. S. de, Santos, A. P. F. do. 2012. Acúmulo e exportação de macronutrientes em melancieiras fertirrigadas sob ótimas condições de adubação nitrogenada e fosfatada. Agropecuária Científica no Semi-Árido 8, 61-70

Trani, P. E., Raij, B. van. 1997. Hortaliças. In: B. van Raij, H. Cantarella, J. S. Quaggio, A. M. C. Furlani (eds). Recomendações de Adubação e Calagem para o Estado de São Paulo (Boletim Técnico, 100). Instituto Agronômico, Campinas, pp: 157-164.
Trani, P. E., Passos, F. A., Nagai, H., Melo, A. M. T. 1997. Melão e melancia. In: B. van Raij, H. Cantarella, J. S. Quaggio, A. M. C. Furlani (eds). Recomendações de Adubação e Calagem para o Estado de São Paulo (Boletim Técnico, 100). Instituto Agronômico, Campinas, pp: 181.

Vidigal, S. M., Pacheco, D. D., Costa, E. L. da, Facion, C. E. 2009. Crescimento e acúmulo de macro e micronutrientes pela melancia em solo arenoso. Rev. Ceres. 56, 112-118.

Walters, S.A. Influence of plant density and cultivar on mini triploid watermelon yield and fruit quality. 2009. HortTechnology. 19, 553-557. 